\title{
Information Technology and Computing Programs in the Universities of West Bengal: An Analytical Case Study
}

\author{
P.K. Paul
}

Executive Director, MCIS and Asst. Professor, IST, Department of CIS, Information Scientist (Offg.), Raiganj University (RGU), West Bengal, India

Corresponding author: pkpaul.infotech@gmail.com

\begin{abstract}
Information and Computing is the core for development of different kind. Computing and Information Technology tools are responsible for information related activities. There are different subjects fall under the computing and IT and among these few important are include Computer Science, Computer Engineering, Computer Applications, Information Science, Information Technology, Informatics, Information Systems etc. However only few are popular among these branch and among these Computer Science, Computer Applications and Information Technology are important one. India is a large country and there are different stakeholders of various means. As far as West Bengal is concerned it is one of the important and active state having good fame in heritage, population and education. There are different educational institutes around the state and many of them offering different level of programs and different nomenclatures in IT and Computing. Conventionally in the universities of West Bengal, one university department offers a specific subject or field. But this study is undertaken to show the differences or changes of thought in this regard. Moreover, the study highlights the degrees offered by the newer and old university as well.
\end{abstract}

Keywords: Universities, Higher Education, Computing, Systems, IT, Academic Degrees, Information Sciences, India, West Bengal

Initially only Computer treated as a field of study with the popular nomenclature of Computer Science. The basic aim of the program was to undertake study and research in the areas of theoretical computation, mathematical sciences; moreover it deals with the core of hardware, design and development of the architecture etc. ${ }^{[1],[5],[7]}$. However, gradually other subjects have been developed which are more applied and industrial in nature and among these important are-

Computer Application

C Computer Engineering

$\square$ Information Technology etc.

Received: 05 June, 2019 
The computing and allied branches are available in two tracks namely Science and Engineering ${ }^{[2],[3],[4],[10]}$. The Science degrees are offered as BSc and MSc whereas Engineering Degrees are comes with BE \& BTech / ME \& MTech. Two important branches which are available both as Science and Engineering Degrees are include-

$\square$ Computer Science and Engineering

$\square$ Computer Engineering

$\square$ Information Technology.

Whereas, Computer Application branch is available as specific MCA Degree (i.e. Computer Application as a full-fledged degree instead of Science concentration-MSc). Though, MCA in academic community treated as a Science degree. In West Bengal there are 40 around universities and many of them are offered IT and Computing Degrees. The degrees are offered in both the university campus and also in the affiliated colleges ${ }^{[8],[9],[15]}$.

\section{Objective}

This paper is theoretical in nature and mainly a case study on Computing and IT related education in the state of West Bengal in India and having following aim and agenda-

$\square$ To learn about the basics of Computing and IT related nomenclature in basic sense; which are available internationally, in India and specifically in India.

$\square$ To know about the degrees available in IT and Computing with special reference to the West Bengal.

$\square$ To know the Universities of West Bengal and also basics on Higher Education in India in general sense.

$\square$ To learn about the IT related degrees, nomenclature and subjects offered in different universities of West Bengal.

$\square$ To know about the departments which are offered multiple subjects in the State of West Bengal in the field of IT and Computing.

\section{IT and Allied Education}

In Computing and IT field, there are diverse subjects and all are concentrated with the tools, technologies related to the computers. And as a result there are different subjects developed and started and among these few important are include as follows-

Computer Science - This is the theoretical concentrated field and mainly mathematical in nature; it is also normally engages in internal affairs of computing. The core aim of the field is design and development of the Computational Systems. Among the core areas of Computer Science important are-Computer Architecture, Operating Systems, Theory of Computation, Compiler Design, AI, Machine Learning, Computational linguistics, Automata Theory etc. ${ }^{[11],[12],[18]}$.

Computer Application - It is a field and area responsible for the applications and systems design and development using software. This is also a field that concentrates on software technology as well. Hence different kind of high level languages are part of the field ${ }^{[14],[15]}$. 
Information Technology - This is the field which is applied in nature and there are difference areas which deals with information related activities ranging from collection to dissemination of information in different format ${ }^{[16],[17],[21]}$. The field is mainly concentrated with different IT Components viz.-

$\square$ Software Technology

$\square$ Web Technology

$\square$ Multimedia Technology

Network Technology

Database Technology etc.

The field is broad enough and applicable in different areas as well.

Information Science - Information Science is an applied science which is depends on IT components due to its several applications. Information Science is an interdisciplinary science; there are different areas where Information Technology may be applied viz. Healthcare, Society, Business, Tourism and Transportation, Media, Government and Administration etc. As a result various areas have become popular in Information Science viz.-

$\square$ E Commerce

$\square$ E Governance

$\square$ E Healthcare

$\square$ Digital Society

$\square$ Digital Business

$\square$ E Business

$\square$ Digital Transformation

E Administration etc.

Moreover there are different branches have created from the Information Science which are concentrated on Healthcare, Business and Commerce, Transportation, Education and Training etc. ${ }^{[22],[23]}$.

\section{Universities in West Bengal}

There are different universities in West Bengal which are categorized into various categories viz. State University, State Private University, Central University, Deemed University apart from the degree awarding bodies viz. Institute of National Importance. However autonomous and centrally funded institutes are another example of higher educational institutes ${ }^{[13],[17]}$.

The following list (Table 1) represents the names of the universities in West Bengal along with the type and category as well herewith. 
Table 1: List of Universities in the state of West Bengal

\begin{tabular}{|c|c|c|}
\hline $\begin{array}{l}\text { Sl. } \\
\text { No. }\end{array}$ & Universities & Category \\
\hline 1 & Adamas University, Barasat, Kolkata, WB, India & Private University \\
\hline 2 & Aliah University, Saltlake, Kolkata, WB, India & State University \\
\hline 3 & Amity University, New Town, Kolkata, WB. India & Private University \\
\hline 4 & Bankura University, Bankura, Kolkata, WB. India & State University \\
\hline 5 & Bidhan Chandra Krishi Vishwavidyalaya, Kalyani, WB, India & State University \\
\hline 6 & Brainware University, Barasat, Kolkata, WB, India & Private University \\
\hline 7 & Cooch Behar Panchanan Barma University, Cooch Behar, WB, India & State University \\
\hline 8 & Diamond Harbour Women’s University, Diamond Harbour, WB, India & State University \\
\hline 9 & Indian Association for the Cultivation of Science (IACS), Jadavpur, WB, India & Deemed University \\
\hline 10 & Jadavpur University, Jadavpur, WB, India & State University \\
\hline 11 & JIS University, Kolkata, WB, India & Private University \\
\hline 12 & Kazi Nazrul University, Asansol, WB, India & State University \\
\hline 13 & Maulana Abul Kalam Azad University of Technology, Saltlake, Kolkata, WB, India & State University \\
\hline 14 & Netaji Subhash Open University, Saltlake, Kolkata, WB, India & State University \\
\hline 15 & Presidency University, College Street, Kolkata, WB, India & State University \\
\hline 16 & Rabindra Bharati University, Kolkata, WB, India & State University \\
\hline 17 & Raiganj University, Raiganj, WB, India & State University \\
\hline 18 & $\begin{array}{l}\text { Ramakrishna Mission Vivekananda Educational and Research Institute, Howrah, } \\
\text { WB, India }\end{array}$ & Deemed University \\
\hline 19 & Seacom Skills University, Bolpur, WB, India & Private University \\
\hline 20 & Sidho-Kanho-Birsha University, Purulia, WB, India & State University \\
\hline 21 & Sister Nivedita University, New Town, Kolkata, WB. India & Private University \\
\hline 22 & St. Xavier’s University, New Town, Kolkata, WB. India & Private University \\
\hline 23 & Techno India University, Saltlake, Kolkata, WB, India & Private University \\
\hline 24 & The Neotia University, Sarisa, WB, India & Private University \\
\hline 25 & The Sanskrit College and University, Kolkata, WB. India & State University \\
\hline 26 & $\begin{array}{l}\text { The West Bengal National University of Juridical Science, Saltlake, Kolkata, WB, } \\
\text { India }\end{array}$ & State University \\
\hline 27 & The West Bengal University of Health Sciences, Saltlake, Kolkata, WB, India & State University \\
\hline 28 & $\begin{array}{l}\text { The West Bengal University of Teachers' Training, Education Planning and } \\
\text { Administration, Kolkata, WB, India }\end{array}$ & State University \\
\hline 29 & University of Burdwan, Burdwan, WB, India & State University \\
\hline 30 & University of Calcutta, Kolkata, WB, India & State University \\
\hline 31 & University of Engineering and Management, New Town, Kolkata, WB. India & Private University \\
\hline 32 & University of Gour Banga, Malda, WB. India & State University \\
\hline 33 & University of Kalyani, Kalyani, WB, India & State University \\
\hline 34 & University of North Bengal, Siliguri, WB, India & State University \\
\hline 35 & Uttar Banga Krishi Vishwavidyalaya, Cooch Behar, WB, India & State University \\
\hline 36 & Vidyasagar University, West Midnapore, WB, India & State University \\
\hline 37 & Vishwa Bharati University, Bolpur, WB, India & Central University \\
\hline 38 & West Bengal State University, Barasat, Kolkata, WB, India & State University \\
\hline 39 & West Bengal University of Animal and Fishery Sciences, Kolkata, WB, India & State University \\
\hline
\end{tabular}


According to the study it has been noted that there are 39 universities in the state and among these 10 are private universities. As far as new universities are concerned it has been noted that 17 universities have been established after 2011 with the category of 'private' and 'state'. Fig. 1 showing the categories of universities in this regard.

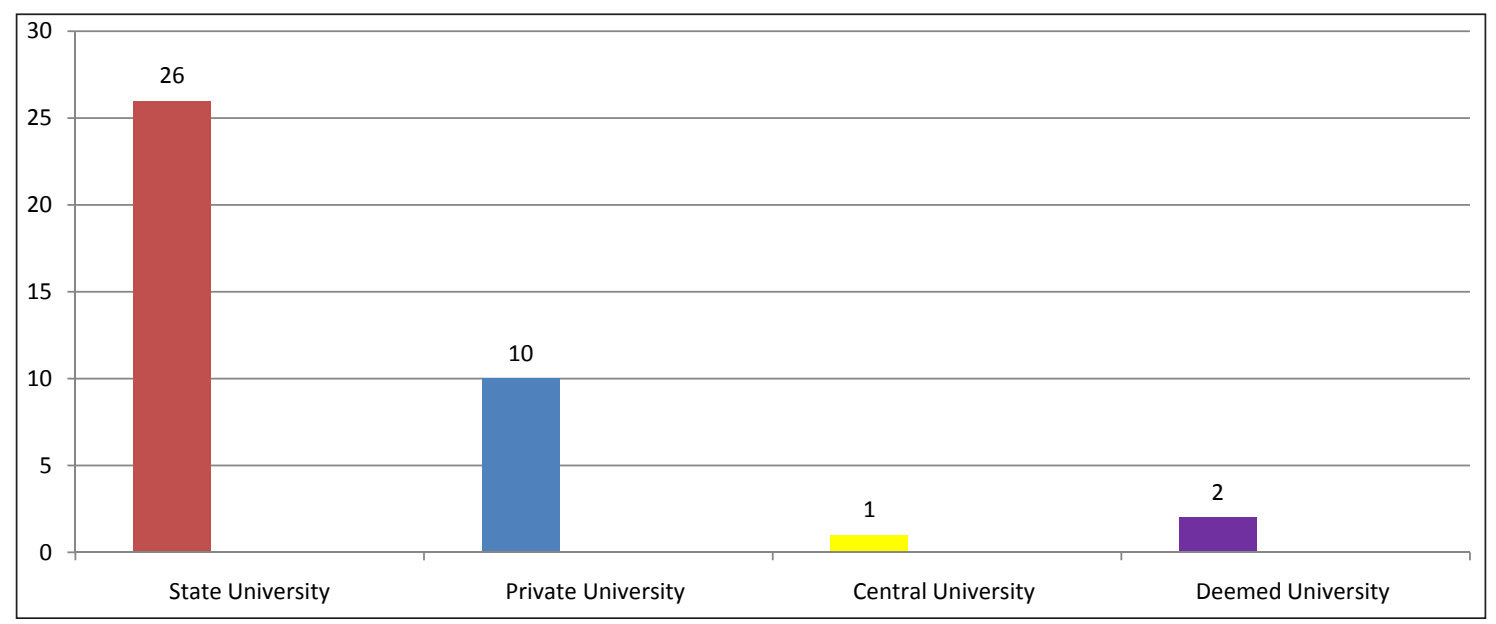

Fig. 1: Categories of Universities in the State of West Bengal

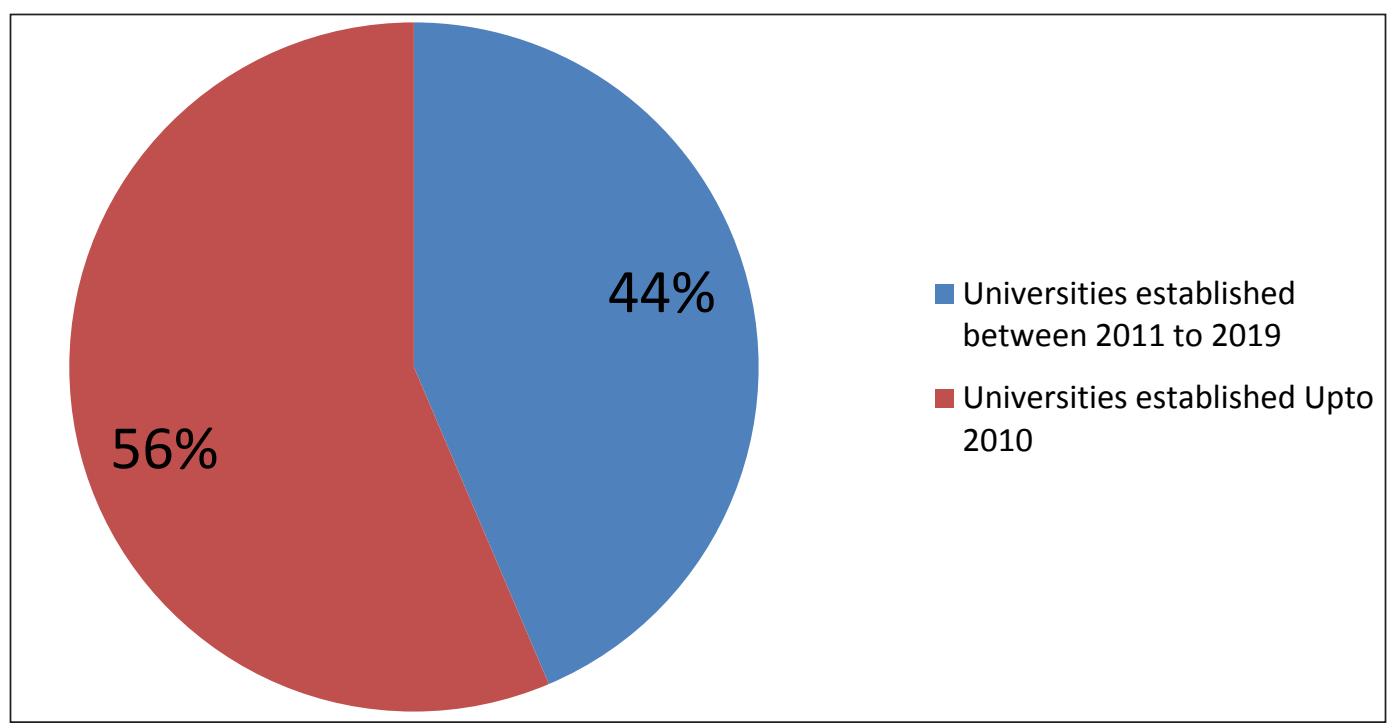

Fig. 2: Sharing of Universities: Recent and Old

Whereas the study also reveals (Refer Fig. 2) that 44 percent of the universities have been came up after 2010 (i.e. since 2011) to till date. However apart from these, there are number of Institute of National Importance in the state namely Indian Institute of Technology, Kharagpur, National Institute of Technology, Durgapur, Indian Statistical Institutes (ISI), Kolkata. Few other centrally funded institutes are also located in the state. 


\section{IT Education in West Bengal: An Analysis}

In the State of West Bengal there are different universities offering computing and IT programs from various departments and among the nomenclature few important are includes the following -

$\square$ Computer Science

$\square$ Computer Science and Engineering

$\square$ Computer Science and Applications

$\square$ Computer and Information Science

$\square$ Computer Applications

$\square$ Information Technology

$\square$ Software Engineering

And these universities are offered both Science and Engineering degrees with BTech/ MTech/ MSc degrees from their in-campus; however no university offers BSc degree from the campus (instead of BCA program of Aliah University).

Table 2: List of Universities in the state of West Bengal with IT and Computing oriented departments

\begin{tabular}{|c|c|c|c|}
\hline University & Department Subject & Programs/ Courses Offered & $\begin{array}{l}\text { Number of } \\
\text { Nomenclature/ Subject } \\
\text { Offered in a Dept. }\end{array}$ \\
\hline $\begin{array}{l}\text { The University of } \\
\text { Calcutta }\end{array}$ & $\begin{array}{l}\text { Dept. of Computer } \\
\text { Science and } \\
\text { Engineering }\end{array}$ & $\begin{array}{l}\text { B.Tech- Computer Science and } \\
\text { Engineering } \\
* \text { MTech- Computer Science and } \\
\text { Engineering } \\
* \text { MSc-Computer and Information } \\
\text { Science } \\
* \text { PhD-CSE } \\
* \text { PhD-CS }\end{array}$ & $\begin{array}{l}\text { 1. Computer Science and } \\
\text { Engineering } \\
\text { 2. Computer Science } \\
\text { 3. Computer and } \\
\text { Information Science }\end{array}$ \\
\hline $\begin{array}{l}\text { The University of } \\
\text { Calcutta }\end{array}$ & $\begin{array}{l}\text { AK Chowdhury } \\
\text { School of Information } \\
\text { Technology }\end{array}$ & $\begin{array}{l}\text { BTech-Information Technology } \\
\text { MTech-Information Technology } \\
\text { * MTech-Computer Science and } \\
\text { Applications } \\
\text { * MCA (Computer Applications) }\end{array}$ & $\begin{array}{l}\text { 1. Information Technology } \\
\text { 2. Computer Applications }\end{array}$ \\
\hline Jadavpur University & $\begin{array}{l}\text { Dept. of Computer } \\
\text { Science and } \\
\text { Engineering }\end{array}$ & $\begin{array}{l}\text { B.Tech- Computer Science and } \\
\text { Engineering } \\
\text { MTech- Computer Science and } \\
\text { Engineering } \\
* \text { MTech- Computer Technology } \\
* \text { MCA (Computer Applications) }\end{array}$ & $\begin{array}{l}\text { 1. Computer Science and } \\
\text { Engineering } \\
\text { 2. Computer Technology } \\
\text { 3. Computer Application }\end{array}$ \\
\hline Jadavpur University & $\begin{array}{l}\text { Dept. of Information } \\
\text { Technology }\end{array}$ & $\begin{array}{l}\text { B.Tech- Information } \\
\text { Technology } \\
* \text { MTech- Software Engineering }\end{array}$ & $\begin{array}{l}\text { 1. Information Technology } \\
\text { 2. Software Engineering }\end{array}$ \\
\hline
\end{tabular}


Maulana Abul Kalan Azad University of Technology

Dept. of Computer

Science and

Engineering

Dept. of Information Technology

Maulana Abul Kalan Azad University of Technology

The University of Kalyani

Dept. of Computer Science and Engineering

Vidyasagar University

Dept. of Computer Science

The University of North Bengal

Aliah University

Raiganj University

The University of Burdwan

West Bengal State University

Diamond Harbour Women's University
Dept. of Computer Science and Applications

Dept. of Computer Science and Engineering

Dept. of Computer and Information Science

Dept. of Computer Science

Dept. of Computer Science

No Department yet Named/ Open
BTech- Computer Science and Engineering

1. Computer Science and Engineering

MTech- Computer Science and Engineering

MTech- Information Technology

BTech-Information Technology 1. Information Technology

* MTech-Information Technology

* MTech-Information Technology (Information Security)

* MTech-Information Technology (Artificial Intelligence)

* MTech-Information Technology (Data Science)

MTech-Information Technology (Internet of Things)

* MTech- Computer Science and Engineering

1. Computer Science and Engineering MCA (Computer Applications) MSc-Computer Science

2. Computer Applications MCA (Computer Applications)

- MSc-Computer Science

1. Computer Science

MCA (Computer Applications)

BCA (Computer Applications)

* BTech- Computer Science and Engineering

2. Computer Applications

1. Computer Science

2. Computer Applications

1. Computer Science and Engineering

2. Computer Applications

* MCA (Computer Applications)

* MTech- Computer Science and Engineering

* BCA (Computer Applications)

* BSc-Computer Science

* MSc-Computer Science

MSc Computer and Information Science

1. Computer Science

2. Computer Applications

3. Computer and Information Science

* MPhil- Computer and Information Science

* PhD-Computer and Information Science

* MSc-Computer Science and Applications

1. Computer Science and Applications

MSc-Computer Science

1. Computer Science

MSc-Computer Science and Applications
1. Computer Science and Applications 
It is worthy to note that among these Departments, The Department of Computer Science and Engineering, The University of Calcutta, WB, India offers three subjects as programs namely-

$\square$ Computer Science and Engineering

$\square$ Computer Science

$\square$ Computer and Information Science

Whereas Department of Computer Science and Engineering, Jadavpur University also offers the three subjects as program leading to degrees in-

$\square$ Computer Science and Engineering

$\square$ Computer Technology

$\square$ Computer Application

Apart from Jadavpur and Calcutta University another university i.e. Raiganj University, West Bengal, India also offers another three programs namely-

\section{$\square$ Computer Science \\ $\square$ Computer Applications \\ $\square$ Computer and Information Science}

Among these branches, Computer and Information Science noted as broad area incorporating IT and Computing related fields. It is worthy to note that, in this study affiliated colleges and programs under these universities are not included. The number of universities with different categories are depicted in Fig: 3.

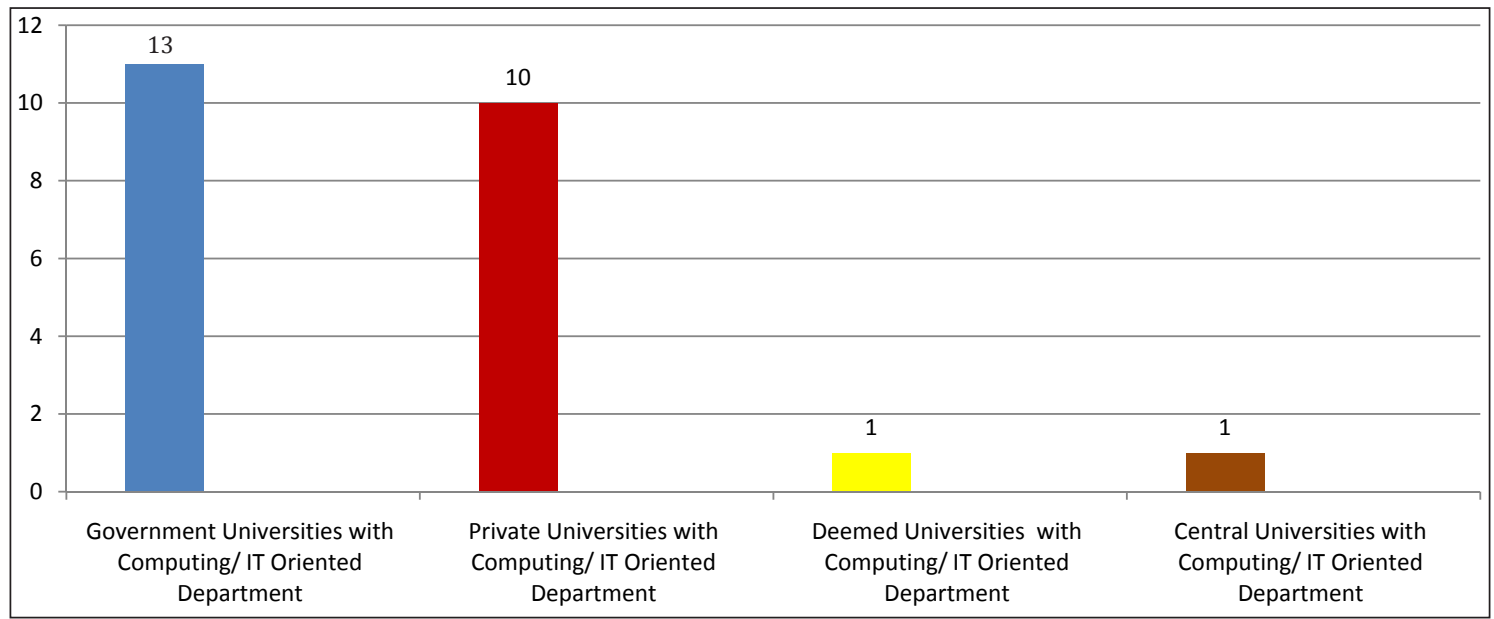

Fig. 3: IT and Computing related departments in Universities

\section{CONCLUSION}

The field of Computing and Information Sciences is changing rapidly different universities are offering various programs on different levels and subjects ${ }^{[19],[20]}$. And even many emerging and super specialty 
areas have been added into this like international and national universities. With this study, it has been noted that within 'Computer' and 'Information' track, the 'Computer' track is most popular and within Information track most common are Information Technology. Among the broad areas, Computer and Information Science is noted at Raiganj University. Whereas the emerging areas are available at MAKAUT viz. Data Science, Information Security, Cyber Security etc. It is important that in future The Departments having more programs or subjects may be converted into the College/ Schools for better functioning, autonomy and infrastructure make available.

\section{REFERENCES}

1. Agarwal, P. 2007. Higher education in India: Growth, concerns and change agenda. Higher Education Quarterly, 61(2): 197-207.

2. Altbach, P.G. 1993. The dilemma of change in Indian higher education. Higher Education, 26(1): 3-20.

3. Basak, S.C. and Sathyanarayana, D. 2010. Pharmacy education in India. American Journal of Pharmaceutical Education, 74(4): 68.

4. Dayal, I. 2002. Developing management education in India. Journal of management Research, 2(2): 98.

5. Desai, S. and Kulkarni, V. 2008. Changing educational inequalities in India in the context of affirmative action. Demography, 45(2): 245-270.

6. Gereffi, G., Wadhwa, V., Rissing, B. and Ong, R. 2008. Getting the numbers right: International engineering education in the United States, China, and India. Journal of Engineering Education, 97(1): 13-25.

7. Gupta, D. and Gupta, N. 2012. Higher education in India: structure, statistics and challenges. Journal of Education and Practice, 3(2).

8. Kapur, D. and Mehta, P.B. 2004. Indian higher education reform: From half-baked socialism to half-baked capitalism. Center for International Development Working Paper, 103.

9. Nambissan, G.B. and Rao, S. (Eds.). 2013. Sociology of education in India: Changing contours and emerging concerns. New Delhi: Oxford University Press.

10. Paul, P.K., Kumar, A., Poovammal, E. and Dangwal, K.L. 2014. Information Science: A Potential interdisciplinary field with Historical Perspectives and Future Potentials. Educational Quest, 5(3): 211.

11. Paul, P.K. and Ghose, M.K. 2018. Why Green Computing and Green Information Sciences Have Potentialities in Academics and iSchools: Practice and Educational Perspectives. In Advances in Smart Grid and Renewable Energy, 435: pp. 103-112, Springer, Singapore.

12. Paul, P.K. and Ghose, M.K. 2018. A Novel Educational Proposal and Strategies Toward Promoting Cloud Computing, Big Data, and Human-Computer Interaction in Engineering Colleges and Universities. In Advances in Smart Grid and Renewable Energy, 435: 93-102, Springer, Singapore.

13. Sharma, Jagdish. 2006. "Diaspora: History of and Global Distribution", Encyclopedia of India (vol. 1) edited by Stanley Wolpert, pp. 331-336, Thomson Gale, ISBN 0-684-31350-2. 
14. Sharma, Shalendra D. 2006. "Globalization”, Encyclopedia of India (vol. 2) edited by Stanley Wolpert, pp. 146-149, Thomson Gale, ISBN 0-684-31351-0.

15. Singal, N. 2006. Inclusive education in India: International concept, national interpretation. International Journal of Disability, Development and Education, 53(3): 351-369.

16. Sood, R. and Adkoli, B.V. 2000. Medical education in India-problems and prospects. J. Indian Acad. Clin. Med., 1(3): 210-212.

17. Sohani, N. and Sohani, N. 2012. Developing interpretive structural model for quality framework in higher education: Indian context. Journal of Engineering, Science \& Management Education, 5(2): 495-501.

18. Supe, A. and Burdick, W.P. 2006. Challenges and issues in medical education in India. Academic Medicine, 81(12): 1076-1080.

19. Tate, D.S. and Schwartz, C.L. 1993. Increasing the retention of American Indian students in professional programs in higher education. Journal of American Indian Education, 21-31.

20. Tayade, M.C. and Kulkarni, N.B. 2011. The Interface of technology and medical education in india: current trends and scope. Indian Journal of Basic \& Applied Medical Research, 1(1): 8-12.

21. Tijerina, K.H. and Biemer, P.P. 1988. The Dance of Indian Higher Education: One Step forward, Two Steps back. Educational Record, 68(4): 86-91.

22. Tilak, J.B. and Varghese, N.V. 1991. Financing higher education in India. Higher Education, 21(1): 83-101.

23. Tilak, J.B. 2008. Transition from higher education as a public good to higher education as a private good: The saga of Indian experience. Journal of Asian Public Policy, 1(2): 220-234.

24. Umashankar, V. and Dutta, K. 2007. Balanced scorecards in managing higher education institutions: an Indian perspective. International Journal of Educational Management, 21(1): 54-67. 